\title{
Educator as Researcher: The Use of Action Research to Explore Effects of Teachers' Corrective Feedback on Students' Microteaching Exercise in College of Education in Nigeria
}

\author{
Daniel Eyisi \\ School of Social Sciences, Education and Social Work, Queen's University Belfast, Northern Ireland, United \\ Kingdom
}

\begin{abstract}
This study examined action research with a view to identifying the importance of using it in teacher education research. The study could be helpful to teacher educators in identifying the student teachers' difficulties in microteaching. It will also assist in finding out student teachers' attitudes towards teacher's corrective feedback. In other to involve learners in the construction of their learning, this study outline will assist teacher education researchers in finding out from student teachers' perspectives, the good practice of teachers' corrective feedback. It will also aim at checking the relationship between teachers' feedback and students' microteaching.
\end{abstract}

Keywords: microteaching, action research, feedback, ethical considerations

DOI: $10.7176 / \mathrm{JEP} / 10-23-07$

Publication date: August $31^{\text {st }} 2019$

\section{Introduction}

I see myself as investigating how my corrective feedback will improve student teachers' teaching skill in microteaching. I have been teaching student teachers microteaching for over a decade to second and third year students in the curriculum department of the College of Education in Nigeria. I chose this topic because, during my first degree programme in education, I did not have the opportunity of having microteaching or feedback from my lecturer which would assist me during the teaching practice exercise and subsequently in the future profession. In view of this, the skills which I was supposed to learn and perfect during microteaching, I learned instead during the actual teaching practice exercise and during my first year in the teaching profession. Despite my feedback to them in their microteaching, the student teachers still do not exhibit some of the teaching skills, and some students exhibit a given skill at an incorrect time. I want to know how my corrective feedback will help improve their teaching skills. I also want to know how they will respond to my corrective feedback to them. I would like to understand my practice so as to transform it and to "transform practice in order to understand it" Aas (2014). I would also like to improve my skills with regard to microteaching feedback so as to help student teachers improve their teaching skills.

\section{Literature Review}

This section will look at the rational for the investigation by reviewing relevant literature with regard to action research, self-study, feedback and microteaching.

\subsection{Microteaching}

Microteaching today can be said to be synonymous with teacher education. It originated at Stanford University in 1963 (McIntyre, MacLeod \& Griffiths, 1977; McGarvey \& Swallow, 1986) as a minute or very small teaching amongst students and their peers. Microteaching was argued by McGarvey \& Swallow $(1986$, p65) to be the first step in the teaching profession, where the first attempt in teaching is usually made within a "low risk situation". The literature suggests that the microteaching goal is to provide real teaching experience to student teachers in a simplified manner. Microteaching is a very small amount of teaching. It is a means of giving preservice teachers the opportunity of having first-hand teaching experience in a very relaxed and cooperative environment (Ajileye and Eyisi, 2013; Momoh, 2013). Microteaching is argued to be the process whereby the student teacher practices some aspect of teaching skills with a small group of students during a small time interval (Okai, Odiachi, Taidi, Garba \& Yusuf, 2005; Bell, 2007). Due to the small number of students and time involved, microteaching can be said to be a scaled-down encounter of the teaching process. Allen \& Ryan (1969) hold that it is a way of improving student teachers' teaching skills by reducing the complexity of the authentic classroom environment through limiting specific variables such as teaching content, number of students and time for the teaching. Looking at what various authors said about microteaching, one may also argue that microteaching is a means whereby the student teacher and the supervisor control some factors that influence the quality of teaching so as to perform better in future practice. Also, this scaled-down teaching encounter can be seen as a means of allowing student teachers to be active in learning and developing competencies and skills that will assist them in their teaching practice. Microteaching has been seen as a clinical approach (Basturk, \& Tastepe, 2015) in that it is teaching how to teach. 
In as much as microteaching "resembles performance or classroom task" (Bell, 2007, pp24), it is a feedback oriented task with the aim of improving student teachers' learning (Ajileye \& Eyisi, 2013). Although Allen \& Ryan (1969) identified six stages in the microteaching model as planning, teaching, observation and feedback, replanning, re-teaching and re-observe, the main focus of this paper will be to document and reflect on the impact of educator' corrective feedback on trainee teachers.

\subsection{Feedback}

Feedback is commonly used not only in the technological and nervous systems but also in teacher education programmes (Sacks, 1999). Feedback is a very important element in any teaching and learning programme which aims to assist students in improving their learning. Feedback is very crucial in educational assessment, especially formative assessment. Educational assessment is classified into formative and summative assessments (Gipps, 1994). Formative assessment is administered by teachers to learners at any time within the academic session to assist them in learning, while summative assessment is administered at the end of an academic session or programme to assign students grades, new classes, certificates or any other administrative purposes as the case may be. Formative assessment is generally known as assessment for learning, and its purpose is to influence the next step of learning and to improve learning through feedback (Gardner, 2006; Evans \& Abbott, 1998). The basic principle of microteaching is the corrective, control and reinforced learning measures in teacher education (Sacks, 1999). Harlen (2006) argued that feedback is a way of creating the impression to the students that their teachers' help and interest in them as students is for them to improve. Weeden, Winter \& Broadfoot (2002) stated that smiley faces, head nodding, ticks and crosses, grades, written and oral comments can be used as feedback to provoke responses that will bring the appropriate learning of teaching skills. It can be said that feedback allows students to know their areas of good and poor performances. This is because feedback focuses on effort and makes students reflect upon their work (what they did wrong and what they will do to improve) to improve their learning (Rhodes, 2009). Feedback, whether verbal or written, should be clearly communicated with readily understandable language without jargon (Boyle \& Fisher, 2007). Microteaching feedback allows student teachers to receive more support and information about their performance during the process (McGarvey \& Swallow, 1986). Also, Alistair (2001) argued that utilising the positive power of microteaching feedback is a means of encouraging student teachers to be aware of the learning process.

Moreover, following the Harlen (2006) argument that information about students' learning from feedback helps to ensure that new teaching skills are neither too difficult nor too easy for the student teachers, one might perhaps believe that feedback helps in regulating the teaching skills learned by student teachers (i.e. that the learning experience for student teachers keep pace with their development). In line with Harlen's argument, Devereux (2001) opined that feedback helps students make sense of their own learning and self-assessment which allows them not only to understand the purpose of learning the teaching skills but also to understand what they need to do so as to achieve that purpose of learning. In recognising the positive power of microteaching feedback, I as a teacher educator, therefore, need to apply the Alistair's (2001, pp113) "feedback principle" to improve my student teachers' teaching skills. In view of this, I will make sure that my feedback is:

- Specific, immediate and educative,

- Devoid of threat, sanction and ambiguity,

- An essential part of microteaching,

- $\quad$ Authentic and more often, the better incorporating positive reinforcement.

\subsection{Action Research}

Kurt Lewin, a social psychologist, is referred to as an originator of action research (Adelman, 1993) because of his work in 1946 (Koshy, 2005). Lewin's work was later developed further by Kolb (1984), Carr and Kemmis (1986) into a conceptual plan. Lewin's work was anchored in Dewey's theory of learning by doing (Dewey, 1929), and interactive conceptual theories structures were acknowledged by Koshy. One form of action research is predicated on the notions of emancipatory study, but Newton and Burgess (2008) argued that action research is not primarily emancipatory, rather it is for improvement. Action research became popularised in education following the "Stenhouse notions of the teacher-as-researcher" (Leitch \& Day, 2000, p178) in which Stenhouse saw teaching and research as being interdependent (McNiff \& Whitehead, 2002). Since then, action research has played an important role in teachers' professional development. Action research, in its ontological and epistemological underpinnings, rejects positivism and is closer to the interpretivist paradigm (Cohen, Manion \& Morrison, 2011). Identifying a problematic situation, imagining its possible solution, trying the solution out, evaluating the solution and using it to change the practice are the basic action principles that underpin action research (McNiff, 2002) which is aimed at improving the practice rather than producing knowledge (Elliott, 1991). These basic action principles are a sequel to approach to action research, which was argued by Kemmis \& McTaggart1982) as participatory, collaborative, systematic and reflexive. Perhaps one can see action research as being explicitly normative and prescriptive in its form as informed by the argument of McGrath \& O'Toole (2016) 
that action research requires the researcher to intervene in an action in professional practice being studied. Action research is argued to be a critical and collaborative inquiry made by the teachers themselves into their own teaching profession (Zuber-Skerritt, 1992) which allows them to study their own classroom (instructional methods, students and assessment), so as to increase their understanding and to improve their effectiveness and quality of teaching (Mertler, 2006).

In spite of the ontological and epistemological complexity of action research (Ahmadian \& Tavakoli, 2011), action research remains a form of self-reflective and self-study enquiry embarked upon by participants in social situations so as to understand and improve their practice and "the situation in which the practices are carried out" (Carr \& Kemmis 1986, p162). This agrees with Elliott's (1991, p52) submission that action research informs a professional judgement that develops practical understanding and wisdom which is the "capacity to discern the right course of action when confronted with particular, complex and problematic states of affairs". I found resilience and comportment in Elliott's as well as Carr and Kemmis' argument about action research, with which I can develop my professional capacity and improve my practice as well. Moreover, Zuber-Skerritts' (1992, p15) action research acronym "CRASP: action research promotes a Critical attitude, Research into teaching, Accountability, Self-evaluation and Professionalism", all of which are important educational goals in the Nigeria education system and thus gives me the zeal in using action research to improve my corrective feedback to student teachers' microteaching practice.

Action research is classified into technical, practical and emancipatory models (Newton \& Burgess, 2008; Leitch \& Day, 2000; Zuber-Skerritt, 1992). Though discussions on these models are beyond the scope of this paper, I must acknowledge the fact that the practical model significantly underpins teachers' corrective feedback to student teachers' microteaching teaching skills practice. Practical action research would help to reveal the impact of corrective feedback on student teachers. This will help me not only to be effective and efficient in my profession through "application of practical judgement and the accumulated personal wisdom" (Leitch \& Day, 2000, p183) but will also contribute to understanding and transforming my consciousness while reflecting on my practice. This was argued by Kemmis (2009) as the transformation of practices, the transformation of understanding and transformation of conditions of practice. I also find action research very important in assisting teacher educators in the improvement of professional practice in view of Wood's $(2009, \mathrm{p} 116)$ argument that action research enables anybody willing to "improve their educational situations to become a knowledge-creator". Action research is a practical way of looking and checking teacher's corrective feedback to ascertain if it will bring the desired improvements, and as such, since it is a form of self-reflective study, perhaps contribute to the reflection on the teacher's experience during teacher training teaching practice exercise (McNiff, 2002; Brydon-Miller \& Maguire, 2009). One would perhaps reason with Keegan's (2016) argument that action research is a flexible approach which gives room for continuous adaptations and changes as the intervention progresses. Keegan is in line with McNiff's (2002) basic action principles, Mertler (2006), Henning, Stone and Kelly's (2009) four stages of action research (planning, acting, developing and reflecting) which highlighted the process involved in the implementation of action research as:

- $\quad$ Reviewing current practice

- Identification of area to be improved

- Imaging the way forward

- $\quad$ Trying it out

- Monitoring the action and evaluating its success.

As a teacher, one can achieve these processes through actions, decisions, discussions, evaluations and revisions (Adelman, 1993) of teacher's corrective feedback to student teachers in microteaching practice exercises. Though Koshy (2005) has argued that action research is for improvement of the work situation and professional development, Adelman (1993), in contrast, has noted that some present advocates of action research are making excessive claims for its impact on policy and practice. Adelman also noted that some advocates are more interested in individual development, neglecting organisational and group development.

However, action research gives room for professional assessment and appraisal. This is because as a teacher, it helps the teacher to build on my previous knowledge, develop and transform the past practice into a new context (McNiff, 2002). Perhaps, in doing action research, one is equally giving an account of oneself. In the teaching and learning situation, feedback is effective if it identifies how work is to be improved (Boon, 2016). It is, therefore, necessary for a teacher to give feedback that gives appropriate direction and guidance about the teaching skills being learnt for proper development of teaching skills by the student teachers, as well as to strengthen teachers in the teaching profession. It was mentioned earlier that action research includes both reflexive and self-study, as argued by Whitehead (1989). I considered action research quite appropriate for this study to enhance reflection on teacher's practice as well as bringing the desired change. Perhaps its collaborative nature will challenge, improve, re-orient the view about teacher's practice and transform it through dialogue (Locke, Alcorn \& O'Neill, 2013). The teaching practice of teachers could be enhanced by action research, specifically by a study that has as its focus the provision of corrective feedback because corrective feedback encourages me as a teacher to consider some 
aspects of my teaching practice and also the new ideas to be gained from how students respond/adapt to the feedback they receive.

\section{Methodology}

In order to improve both student teachers' teaching skills and teacher educator's own practice using corrective feedback, I have to reflect on the questions put forward by McNiff and Whitehead (2002, p72) as stated below;

- What is my concern?

- Why am I concerned?

- What do I think I can do about it?

- What will I do about it?

- How will I gather evidence to show that I am influencing the situation?

- How will I ensure that any judgements I make are reasonable, fair and accurate?

- What will I do then?

I may say that the answer to these questions is the hallmark of an investigation into the teacher educator's corrective feedback.

\subsection{Design of Study}

The study is purely action research, targeting a population of second year student teachers at the College of Education in Nigeria who will be going for their teaching practice exercise in their first semester of the three hundred level. The 20 student teachers in the class will be invited to participate, depending on their consent, but only 10 students will be used for the study. The 10 will be selected based on their display of low teaching skills on the microteaching exercise.

\subsection{Methods}

Participatory research methods are considered relevant for this action research. The activities include the learning of teaching skills such as set induction, stimulus variation, examples and illustrations, questioning, explanations, communication and microteaching practicum (Allen \& Ryna, 1969; Brown \& Armstrong, 1975). The study will start with a focus group of 5 student teachers, which will serve as an advisory group, and this will be part of a cohort of 10 student teachers chosen for the study. This will provide me with an opportunity to refine the questions in the semi-structured interview, as well as reflecting on my own practice. This focus group will help me jointly construct the study with the student teachers for the main study.

In the study, while they are demonstrating the teaching skills which they have learnt, their teaching will be video recorded for further analysis (if they agree to the video recordings) and give them feedback on their practice. At the end of this session, questions will be administered similarly to the initial interview and any other specific questions relevant to the session. In comparison to their initial and second interview, their demeanor will be examined from the video recordings and transcribe them to help make modifications where necessary. The study will exploit semi-structured interviews and observations before and after the intervention. The intervention will consist of lessons on different teaching skills. McNiff \& Whitehead's (2002, p72) questions would be useful in planning methodology, as stated earlier. Perhaps I will consider my responses to each of their suggested questions outlined below as all are embedded in my main study. These are:

3.2.1 What is my concern?

The purpose of microteaching is to enable the student teachers to develop and practice the teaching skills and qualities that will enhance their professional competence. My concern is that some student teachers in my class do not possess the necessary teaching skills, while some who possess some of the skills do not know how to put them into practice. If I do not give them corrective feedback in their microteaching (the formative period in the teaching profession), it may have negative consequences on their future teaching career.

3.2.2 Why am I concerned?

Through observation of my students and several years of supervising student teachers on teaching practice, I have found that some student teachers do not teach well. This is either because they do not possess or do not perfect the teaching skills. I am conscious of this problem because I was a victim of the same problem during my training as a teacher because I was not given the necessary practical training and corrective feedback. Moreover, I see it as my responsibility as the student teachers' teacher, guide, advisor and assessor to address all issues relating to teaching skills which my student teachers need to possess before going to practice the profession. This is an effective use of self-reflection to inform the teacher's current practice.

3.2.3 What do I think I can do about it?

I would like to implement, appraise and refine my corrective feedback interventions (action research is iterative and cyclical). This is because it is the area of my interest, and I hope my corrective feedback will assist my student teachers in developing and perfecting their teaching practice skills. I consider corrective feedback necessary 
because some of the student teachers who cannot teach or exhibit teaching qualities do have the ability to take comments made on their class assignment seriously.

3.2.4 What will I do about it?

In line with the democratic and collaborative participatory principle of action research (Zuber, 1992; Thompson, 2004), I will, first of all, discuss with the focus group of five student teachers my intention to study the ways to improve their teaching skills using corrective feedback. I will discuss with them their teaching skills experiences in the school. The information I receive from the focus group will assist me in planning the research and intervention (series of microteaching practice lessons and corrective feedback). Each of the 10 student teachers chosen will teach and reteach only in four different lesson sessions of a twelve-week semester session. Each session will last for two hours during which each student teaches for only 20 minutes, and critique from participants will take 10 minutes. I will reflect further on the lesson with the help of video recordings made during the presentation. At the end of the twelve-week lesson session, the student teachers will be interviewed again about their microteaching experiences. I will use this interview and the initial one to see if there are any similarities.

3.2.5 How will I gather evidence to show that I am influencing the situation?

I will gather evidence through discussions with the focus group. This will help me in structuring three semistructured individual interviews and questionnaires. The first one will be administered before beginning the process, and the second after each of the student has completed the four microteaching practice sessions. My observation notes will be supplemented by the student teachers' short self-reflection after every two microteaching practices. A personal diary of my own observations and comments together with the peers' critique will be kept secured. I will also securely store the video recordings of every student teacher's teaching session. I may also wish to note if any student teachers have any additional recording of practical teaching skills with their peers outside our scheduled practice sessions.

3.2.6 How will I ensure that any judgements I make are reasonable, fair and accurate?

I judge my practice in terms of whether my corrective feedback on student teachers' microteaching practice substantially increases student teachers' teaching skills (McNiff \& Whitehead, 2002). I do not rely only on my own observations. From the start of the study, I will have formed validation groups. The first was the focus group followed by the collaborative group (participants) which includes a colleague in the department who will be invited to observe and report on the microteaching sessions and the corrective feedback offered to student teachers. I will adopt listening, discussion and interviewing approaches because they are interactive, democratic and immediate which have been argued by Weeden, Winter \& Broadfoot (2002) to be good for both formative and summative purposes. I will make sure that each student teacher is given equal opportunity to practice in terms of teaching duration, comments, class venue and teaching materials. I will avoid influencing and interfering with the students' teaching by other student teachers. I must also ensure that all the student teachers are fully informed.

3.2.7 What will I do then?

In order to improve my practice and student teachers' opportunities for learning teaching skills, I must "find ways to create the conditions for the dialogue of thinking together" (Wells, 2009). I will, therefore, introduce corrective feedback to the student teachers' microteaching practice, which will give them the opportunity to appraise their performance (skills they did well and skills which they need to improve upon).

I will give the student teachers the opportunity to critique, comment and also celebrate their success rather than emphasising only on their mistakes, failures or inadequacies.

I will introduce a democratic and collaborative participatory approach to the student teachers' microteaching practice.

I will write my findings using the evidence based on the personal diary of my notes, observations and student teachers' responses, as well as the video recordings. Also, I will analyse my initial interviews in conjunction with the final interview.

Perhaps, I will acknowledge any form of limitations and implications for my future practice or for others wishing to practice in this area. After all, one of the fundamental aims of practical action research is enhanced practice for all participants and stakeholders, myself and other teachers included.

\section{Ethical Considerations}

Proper conduct is required in carrying out research with human participants. No matter the approach and methods adopted in the research, it is argued that ethical issues "lurk in any research involving people" (Robson, 1993, p30). Action research is a research approach that deals with human participants as collaborators in democratic settings rather than regarding people as subjects. Action research researchers must acknowledge their interpersonal bonds to other people and be ready to take responsibility for their actions and consequences (Ellis, 2007). Also, action research is conducted in a real-world situation in which much responsibility is placed on the research participants who continuously reflect on their action, taking cognisance of emerging ethical issues. Perhaps, action research demands a high degree of moral justification as Leitch \& Day (2000) noted from Dewey's (1933) work that responsibility, open-mindedness and whole heartedness are considered attitudes which can predispose a person to 
reflect upon their actions. Although action research often raises its own issues as one is solved (Robson, 1993), its ethical issues may never be completely addressed (Zeni, 1998). Zeni stated that the researchers must seek permission and explain the general nature of the research as well as the participants' involvement. Safety of the participants is a crucial issue as the researcher is expected to adhere to the rules of confidentiality and be transparent in all the approaches. Also, the participants' right to participate in or withdraw from the research must be acknowledged by the researcher (Scally, 2014; Baumfield, Hall \& Wall, 2008).

In any research involving vulnerable children and young adults, ethical considerations need to be fully applied non-contentiously and with extra care to safeguard their safety, right and well-being. With regard to this study, I would make it known to the participants that I am conducting research and give reasons for inviting them to participate in the research. In looking at the ethical consideration for this research, I will adopt McNiff, Lomax \& Whitehead's (1996) ethical guidelines for conducting research with people. The guidelines are:

\subsection{Negotiate Access}

Action research is argued to be a collaborative practice that involves sharing responsibilities for learning (Keegan, 2016). This collaborative nature of action research will perhaps bring me closer to the students and increase my skills of listening to their contributions, as well as acting upon such contributions. To do this, I would negotiate and get formal and official permission in writing to do my study before I begin the research. I would send letters to all the participants, my colleague and college authority. I would explain with honesty what I plan to do (what I may do and what I may not do). The times of teaching, criticism/comments and interviews would be clearly outlined. I would make it clear to the participants from the beginning that they are co-researchers and not subjects that I am going to study. In view of this, I will always keep them informed and involved throughout the research because they are central to my research.

\subsection{Promise Confidentiality}

From the start of the study, I would tell the participants that I am researching my own practice and not their own practice. In order to protect my participants, information and data, I would maintain a high level of confidentiality. To this end, I would use pseudonyms and not real names of people or schools even in my field notes as stated by various authors (Zeni, 1998; Baumfield, Hall \& Wall, 2013; Stang, 2015). I would give full assurance that I will not disclose anything of a personal nature. Excerpts from the video recording would be checked thoroughly to make sure that my perceptions of the students' teaching are accurate.

\subsection{Participants' right to withdraw from the research}

Participants are usually considered free from risk if they can withdraw or refuse to participate without any penalty (Stang, 2015; Baumfield, Hall, \& Wall, 2008). I would make sure that participants' participation is voluntary (Scally, 2014), and that they are always comfortable in their involvement with the proceedings. I would also make it clear that they have the right to withdraw anytime they wish, without penalty and that their rights are highly protected.

\section{4 keeping other informed}

When inviting people to participate in the research, they need to be fully informed about the research (Bryman, 2012). I would let the participants know what I am going to do from the start without deception (Cohen, 2011). I would produce the plan for the research (time, duration and venue for lessons) at the beginning and present it to them. I would also make their progress reports, comments and feedback available to them in a way that they will have confidence in the research and can verify the report since it is their responses that I am interpreting (Koshy, 2005).

\subsection{Maintaining my own intellectual property rights}

This study is important for my own professional development. In view of this, I would be aware of students' reflexivity and subjectivity when I am analysing class contributions, lesson notes, transcripts and video recordings to extract categories and themes. To this end, I would be careful of my own bias, interpretations, reflexivity, subjectivity and accuracy so that a maximum amount of reliability and validity can be obtained in my report.

\subsection{Keeping good faith}

As a researcher, I would take responsibility for all my actions. I will be aware that as I address one issue, others that need my attention might emerge (McNiff, 2002). Perhaps, I may not be able to get all information that will enable me to inform participants everything about the research due to the fact that I may not accurately predict the student teachers' responses and teaching patterns. Nevertheless, I would assure them from the beginning that I will keep to my promise of maintaining their confidentiality and negotiating with them at all time. I will write down what I hope to do and get approval for it should there be any misunderstanding, but I will work to adhere strictly 
to ethical guidelines.

\section{Limitations}

Reflective thinking is very important in action research. I have acknowledged the principle of reflexivity, which stands as a limiting factor in this research. While interacting with the participants in this research, I am aware of the effect of my personal experiences. I am reflective about my values, methods and decisions (Bryman, 2012) in relation to what student teachers do or tell me throughout the microteaching practice process. Knowing fully that I am researching my own practice, the students may perhaps wish to impress and assist me by telling me what they think I would like to hearthe and this may affect my research findings. Also, the study will use a small sample size and one school due to its qualitative nature. In view of this, generalization may not be possible (Robson, 1993).

However, Elliott (1991) stated that the aim of action research is to improve practice and not to produce knowledge. If my corrective feedback improves student teachers' teaching skills, then my practice will be enhanced by using corrective feedback methods. Though, due to time constraint and non-flexibility of college timetable, the research could not consider gender issues on my corrective feedback on student teachers' teaching skill. But I believe that the research findings will significantly improve my future practice.

\section{Conclusion}

This proposal looked at student teachers' teaching skills. It focused on using corrective feedback to improve student teachers' teaching skills during microteaching practice. Action research was considered for this study because its aim is to improve researchers' professional practice and to produce new knowledge. The research method regards all participants as collaborators and co-researchers and not subjects to be researched on. The student teachers will be given lessons on teaching skills for some weeks after which they will teach (practice the skills) followed by corrective feedback and appraisal. They will reteach and be appraised again. The study gives them an opportunity to appraise themselves and be appraised by other participants too.

As I will be reflecting on my professional practice, I would also be conscious of students' reflexivity and subjectivity while analysing my data. The reflexive and subjective nature of the action research would be a kind of limiting factor to this research. The research is collaborative and participatory with young adults, and so the issue of ethical consideration would be taken seriously in order to not to put the participants at risk. This research offers me the opportunity not only to use my corrective feedback to improve student teachers' teaching skills. It will also allow me to reflect and improve my professional practice, as well. This proposal was highly aided and motivated by McNiff and Whitehead's (2002) series of questions with regard to action research, and I believe this study will go a long way towards enhancing teacher educators professional.

\section{References}

Aas, M. 2014, 'Towards a reflection repertoire: using a thinking tool to understand tensions in an action research project', Educational Action Research, 23 (3), p441-454.

Adelman, C., 1993, 'Kurt Lewin and Origins of Action Research' Educational Action Research' 1(1), pp7-24.

Ahmadian, M. J. \& Tavakoli, M., 2011, 'Exploring the utility of action research to investigate second-language classrooms as complex system', Educational Action Research, 19 (2), pp121-136.

Ajileye, A. M., \& Eyisi, D., 2013, 'The Concept and Process of Micro-Teaching' in Adole, I, Udom, G. I., Ajileye, A. M., Eyisi, D., Olugbemi, O., Momoh, A. I., Onwu, O., Idowu, O., and Popoola, M. F., (Eds) Essentials of Microteaching, Abuja, Yinkus \& Sons Enterprises.

Alistair, S., (2001), 'What the most recent brain research tells us about learning', in Banks, F \& Mayes, A. S., (Eds) Early Professional Development for Teachers, London, Open University Press.

Allen, D. \& Ryan, K., 1969,' Microteaching, Reading, Massachusetts, Addicson-Wesley publishing Company.

Basturk, S. \& Tastepe, M., 2015, 'Examining Primary Pre-Service Teachers' Difficulties of Mathematics Teaching with the Microteaching Method', Acta Didactia Napocensia, 8(3), pp1-10.

Baumfield, V., Hall, E. \& Wall, K., 2008, 'Action Research in the Classroom' London, SAGE Publications Ltd.

Baumfield, V., Hall, E. \& Wall, K., 2013, $2^{\mathrm{ND}}$ Edition, 'Action Research in Education', London, SAGE Publications Ltd.

Bell, N., D. 2007, 'Microteaching: What is it that is going on here?' Linguistics And Education, 18 (1), pp24-40.

Boon, S. I., 2016, 'Increasing the uptake of peer feedback in primary school writing: findings from an action research enquiry', Education, 3-13, 44(2), pp212-225.

Boyle, J. \& Fisher, S., 2007, 'Educational Testing: A Competence-Based Approach', USA, Blackwell Publishing.

Brown, G., \& Armtrong, S., 1975, 'More About Microteaching Trend in Education, London, Mothuence and Co Ltd.

Brydon-Miller, M. \& Maguire, P., 2009, 'Participatory Action Research: Contributions to the development of practitioner inquiry in education, Educational Action Research, 12(2) pp79-93).

Bryman, A., 2012, $4^{\text {th }}$ Edition, 'Social research methods', New York, Oxford University Press. 
Carr, W. \& Kemmis, S. 1986, 'Becoming critical: Education, knowledge and action research', London, Falmer.

Cohen, L., Manion, L. \& Morrison, K. 2011, $7^{\text {th }}$ Edition, 'Research Methods in Education', Abingdon, Routledge.

Devereux, J., 2001, 'Pupils voices: discerning views on teacher effectiveness', in Banks, F. \& Mayes, A. S. (Eds) Early Professional Development for Teachers, London, The Open University \& David Fulton Publishers.

Dewey, J. 1929, 'The source of a science of education', New York, Liveright.

Elliott, J., 1991, 'Action Research for Educational Change: Developing Teachers and Teaching', Buckingham, Open University Press.

Ellis, C. 2007, 'Telling Secrets, Revealing Lives: Relational Ethics in Research with Intimate Others', Qualitative Inquiry, 13 (1), pp3-29.

Evans, L. and Abbott, I., 1998, 'Teaching and Learning in Higher Education' London, Cassell Wellington House.

Gardner, J., 2006, 'Assessment and Learning: An Introduction' in Gardner, J., (Ed.) Assessment and learning, London, SAGE Publications.

Gipps, V. C., 1994, 'Beyond Testing: Towards a Theory of Educational Assessment', London, The Falmer Press.

Goodnough, K., 2010, 'The Role of Action Research in Transforming Teacher Identity: Modes of Belonging and Ecological Perspective', Educational Action Research, 18(2), pp167-182.

Harlen, W., 2006,'On the Relationship Between Assessment for Formative and Summative Purposes' in Gardner, J. (Eds) Assessment and Learning, London, SAGE Publications Ltd.

Henning J. E., Stone, J. M. \& Kelly, J. L., (2009), 'Using Action Research to Improve Instruction: An Interactive Guide for Teachers, London, Routledge, Taylor and Francis.

Hopkins, D., 2008, $4^{\text {th }}$ Edition, 'A Teacher's Guide to Classroom Research' Berkshire, Open University Press.

Keegan, R., 2016, 'Action Research as an Agent for Enhancing Teaching and Learning in Physical Education: A Physical Education Teacher's Perspective' Physical Educator, 73(2), pp 255-284.

Kemmis, K., 2009, 'Action research as a practice-based practice,' Educational Action Research, 17(3), pp463-474. Kemmis, S. \& McTaggart, R., 1982, $3^{\text {rd }}$ Edition, 'The Action Research Planner' Victoria, Deakin University Press.

Kolb, D., 1984, 'Experiential Learning: Experience as The Source of Learning and Development', New Jersey, Prentice-Hall.

Koshy, V., 2005, 'Action Research for Improving Practice: A Practical Guide’ London, Paul Chapman Publishing, A SAGE Publications.

Leitch, R. \& Day, C., 2000, 'Action research and reflective practice: towards a holistic view', Educational Action Research, 8 (1), pp179-193.

Lewin, K., 1946, 'Action Research and Minority Problems' Journal of Social Issues, 2(4), pp34-46.

Locke, T., Alcorn, N., \& O’Neill, J., 2013, 'Ethical Issues in Collaborative Action Research', Educational Action Research, 21(1), pp107-123.

McGarvey, B., \& Swallow, D., 1986, 'Microteaching in Teacher Education \& Training', London, Croom Helm Ltd.

McGrath, H. \& O’Toole, T. 2016, 'Using action research and action learning for entrepreneurial network capability development', Action Learning: Research \& Practice, 13(2), p118.

McIntyre, D., MacLoed, G. \& Griffiths, R., 1977, 'Investigations of Microteaching', London, Croom Helm Ltd.

McNiff, J. 2002, $3^{\text {rd }}$ Edition, 'Action Research for Professional Development: concise advice for new action researchers', http://www.jeanmeniff.com. Accessed $3^{\text {rd }}$ June, 2016.

McNiff, J. \& Whitehead, J., 2002, 2 ${ }^{\text {nd }}$ Edition, 'Action Research Principles and Practice, London, RoutledgeFalmer.

Mertler, C. A., 2006, 'Action Research: Teachers as Researchers in the Classroom', California, SAGE Publications, Inc.

Momoh, A. I., 2013,'Relevance of Microteaching to Teacher Education Programme' in Adole, I, Udom, G. I., Ajileye, A. M., Eyisi, D., Olugbemi, O., Momoh, A. I., Onwu, O., Idowu, O., and Popoola, M. F., (Eds) Essentials of Microteaching, Abuja, Yinkus \& Sons Enterprises.

Neni, J., 1998, ‘A guide to ethical issues and action research’ Educational Action Research, 6 (1), pp9-19.

Newton, P \& Burgess, D., 2008, 'Exploring Types of Educational Action Research: Implications for Research Validity' International Journal of Qualitative Methods, 7(4), pp18-30.

Okai, A., Odiachi, E., Taidi, J. L., Garba, U, K., \& Yusuf, B., 2005, 'Curriculum and Instruction Made Easy' Minna, A publication of Curriculum and Instruction Department, Niger State College of Education.

Rhodes, R., 2009, 'What - no grades? An action research project in assessment for learning' in Lawson, A. (Eds) Action Research: Making a Difference in Education, Vol 1, Slough, NFER.

Robson, C., 1993, 'Real World Research: A Resource for Social Scientists and Practitioner-Researchers', Oxford, Blackwell Publishers.

Sacks, O., 1999, 'Making up the Mind', in Murphy, P. (Eds), Learners, Learning \& Assessment, London, The Open University Press.

Scally, A., 2014, 'Ethical issues in research involving children and young people', Radiography, 20(3), pp202205. 
Stang, J., 2015, 'Ethics in Action: Conducting Ethical Research Involving Human Subject: A Pimer', Journal of the Academy of Nutrition and Dietics, 115(12), pp2019-2022.

Thompson, V. 2004, 'Disability and empowered: personal and integrity in further education research' in Armstrong \& Moore, M., (Eds) Action Research for Inclusive education: Changing Places, Changing Practices, Changing Mind, London, RoutledgeFalmer.

Weeden, P., Winter, J \& Broadfoot, P., 2002, 'Assessment: What's in it for Schools?'

Wells, G., 2009, 'Dialogic Inquiry as Collaborative Action Research' in Noffke, S. \& Somekh, B., (Eds), The SAGE Handbook of Educational Action Research, London, SAGE Publications Ltd.

Whitehead, J., 1989, 'Creating a Living Educational Theory from Questions of the kind: How do I improve my practice?' Cambridge Journal of Education, 19(1), pp37-41.

Whitehead, J. \& McNiff, J., 2006, 'Action Research: Living Theory, London, SAGE Publications Ltd

Wood, L., 2009, 'The transformative potential of living theory educational research', Educational Journal of Living Theories, 3(1), pp105-118.

Zuber-Skerritt, O., 1992, 'Action Research in Higher Education: Examples and Reflections' London, Kogan Page Ltd. 